\title{
INTERACTION OF ARCHITECTURE AND SOCIETY: PUBLIC PROCUREMENT AS TOOL TO IMPROVE LOCAL ECONOMY AND ARCHITECTURE
}

\author{
Jonas Jakaitis \\ Dept of Urban Engineering, Vilnius Gediminas Technical University, \\ Sauletekio al. 11, LT-10223 Vilnius, Lithuania \\ E-mail: jonas.jakaitis@vilnius.lt \\ Submitted 24 Nov. 2007
}

\begin{abstract}
One of the main tasks of public authorities is to find ways how, in the course of the development of urban architecture, to manage and create assumptions for the public to become a new-type, active and cooperative civic society taking part in urban development processes. The research of these problems is important seeking to ensure sustainability in natural, economic-social environment and urban architecture. Assessing the features for application of democratic principles in planning in Lithuania the main objective of this paper is to try to reveal the problems of quality in the development of urban architecture in the context of public procurement of services and to assess the efficiency of procedures defined by legal acts from the viewpoint of architectural quality. Interdisciplinary, comparative analysis methods are used to achieve this objective by revealing the particularity of momentary events.

The paper is prepared on the basis of URBACT/LCS (Leveraging City Services) conference of November 2007 (Hudson 2007) (Jakaitis 2007); besides, analysis by S. Mockaitis of Vilnius City Municipality practical experience was used.

Keywords: urban architecture development; public procurement of services; sustainable territorial development; public participation in planning process; complexity and integrated management of urban architecture development.
\end{abstract}

\section{Introduction}

The application of West European democratic principles, when the public takes part in the process of developing urban architecture, and of management experience in Lithuania in the course of changing political, economic-social environment, in principle, decides upon regular changes of economic, legal and social ways in development of urban architecture under the market conditions. The integration process to global structures, including the European Union, is going on. The relationship between state, municipal and economic entities (enterprises) and population is changing too. More and more attention is paid to sustainable development of territories, improvement of life quality, ecology and other issues. Local government does not fully ensure the fulfillment of self-governing functions and under the influence of different factors does not always succeed to maintain the initiative of an urban planner and architectural developer because, unlike in the countries with long-term democratic planning traditions, municipalities in

Lithuania are not the owners of their own territories (this is in the ownership of the State). It means that private subjects: the public, territorial communities and, especially, real estate developers become the participants and initiators of urban architecture development.

The cooperation based on democratic planning principle is more and more active and contributes to the quality improvement of urban life getting involved the politicians of capital city municipality, specialists, non-governmental organizations (NGO), informal public bodies, and territorial communities (TC) (Fig. 1). If, according to R. Buivydas (1998), citizens have no opportunities to participate actively and become aware of their role in the above process, most of them will always remain detached observers of democratic development, unable to participate in collective decision-making or discussion about the ways of creating common wealth.

Assessing the features for applying democratic planning principles in Lithuania the main objective of this paper is to try and reveal the problems of quality in urban architecture development in the context of public procurement of services, to assess the efficiency of procedures defined by legal acts from the viewpoint of architectural quality. Interdisciplinary, comparative analysis methods are used to achieve this objective by highlighting specific moments of events. 


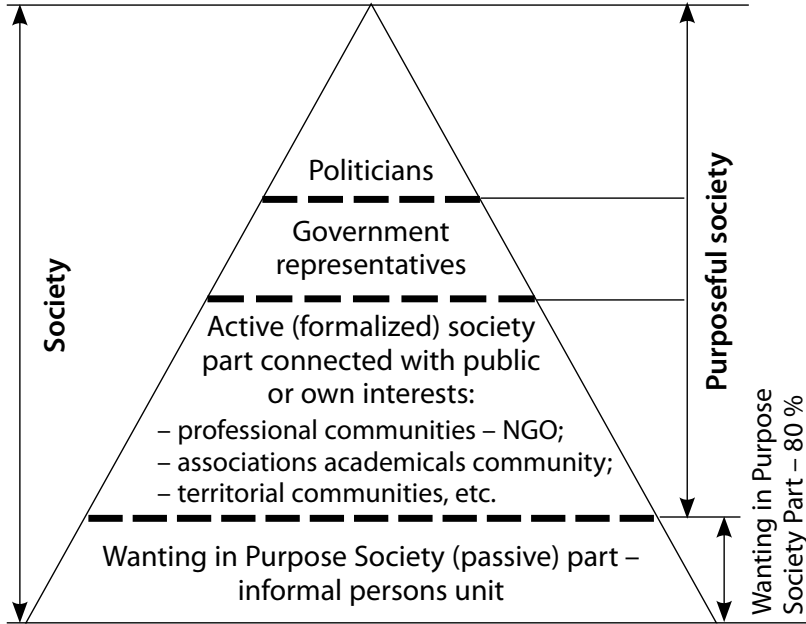

Fig. 1. Society model of cognition

\section{Historical and contemporary regulation of Lithuanian planning system and architectural activity quality}

In the directives of the European Union the concept "public interest" serves as a qualitative indicator of architectural performance. Definition of the latter is important not only for architects, urban planners but also for the entire society. In a globalising world, as economic subjects as well as architects are expanding their activities not only in Lithuania but also in the EU or other world regions, it is necessary to standardise the results of architecture and society interaction by defining qualitative criteria of architectural performance.

According to K. Hudson (2007), providing $80 \%$ of all jobs and most local economic growth, businesses with fewer than 50 employees are the lifeblood of urban economies. Most managers believe that public procurement law makes this unavoidable. They are wrong. LCS (Leveraging City Services) project research demonstrates that local government can empower public procurement professionals to promote territorial economic growth and social cohesion through better management of the global procurement process, increased staff professionalism and affirmative small-business friendly policies and procedures. These changes enable qualified businesses with fewer than 50 employees - often excluded by current procedures - to respond to competitive tenders and win.

A manner of public procurement by announcing of tenders, as a well-known means of improving the quality of architectural performance, was spreading in the West Europe touching not only Lithuania but also the entire space of the Russian tsar regime. In the late 19th

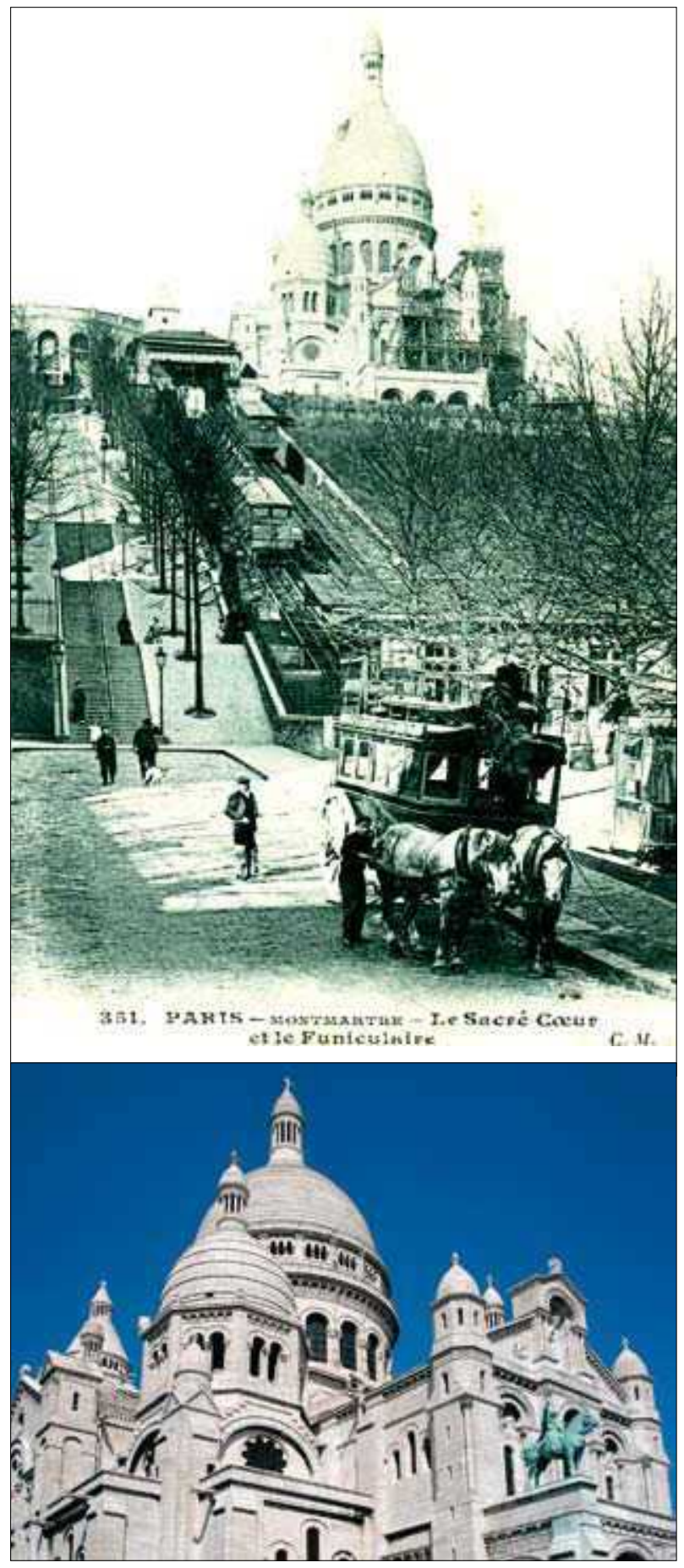

Fig. 2. Basilica of the Sacred in Paris (Sacre-Coeur) (author's photos)

century - early 20 th century in the great European cities architects, who had won open, visiting or commissioning tenders, were in charge of constructions of major buildings. According to N. Lukšionytė-Tolvaišienè, tenders for engineering and construction were encouraging creativeness of architects and marked the evolution of democratic principles (Lukšionytė-Tolvaišienè 2002: 

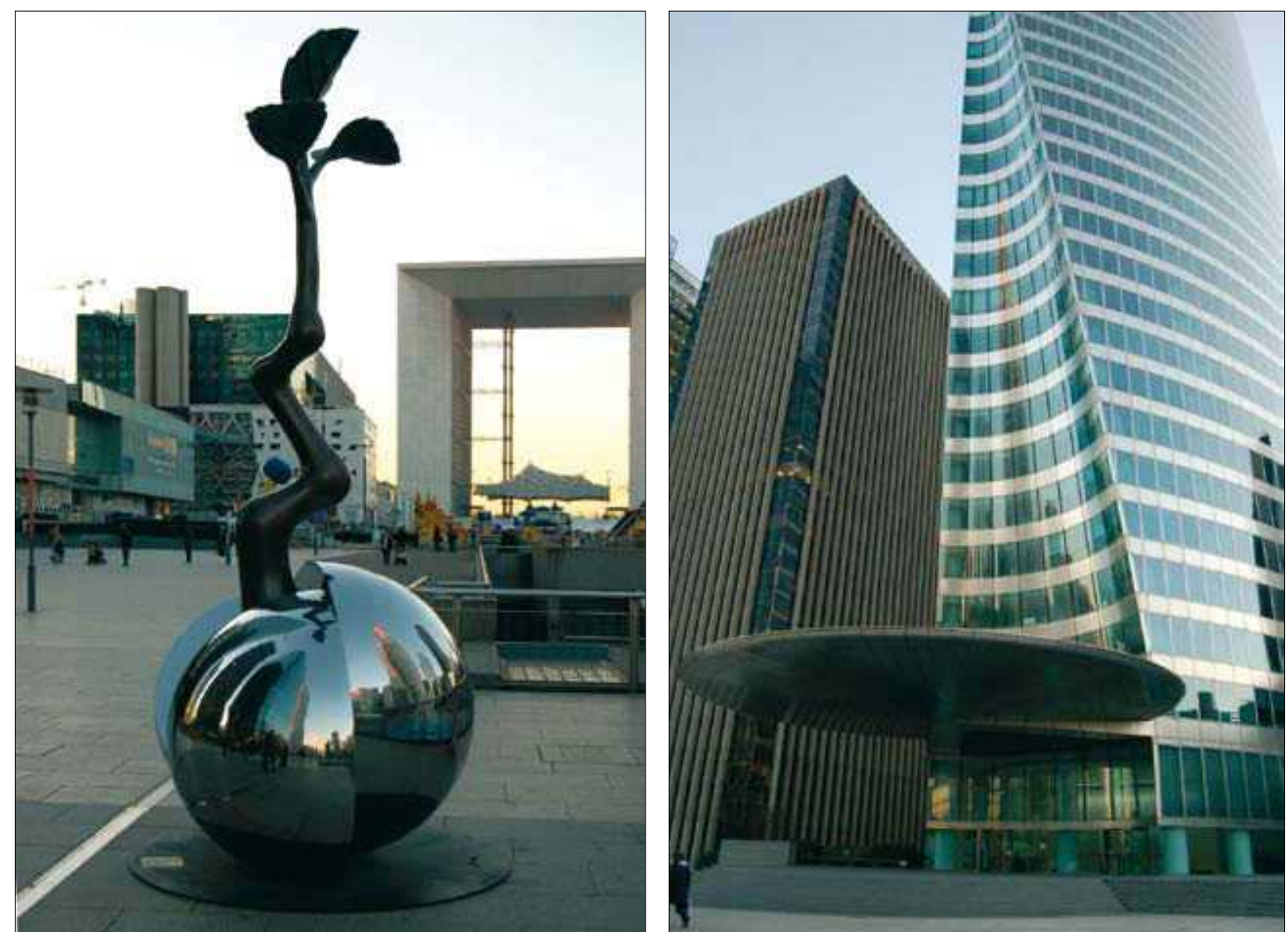

Fig. 3. High-tech style of architecture in Paris (La Defanse) (author's photos)

95). Architects of the French historicism in the late 19th century extremely popularized the neo-romanticism. This trend was particularly unfolded in tender projects for the Sacred Heart Church on Montmartre hill in Paris in 1874-1875 (Fig. 2). In 1873 the city council of Paris voted a law of public utility to seize land at the summit of Montmartre for the construction of the basilica. The architect Paul Abadie designed the basilica after winning a competition over 77 other architects.

At that time there was a tendency for engineering churches and other objects important for society by the way of competitive selection. There, in 1903 the Sacred Heart Church in Cracow was to be built after announcing a closed tender (in the context of this paper - nonformal way of organising a tender. - J. J.), to which architects from Poland, Vienna and a famous Lithuanian architect A. Vivulskis were invited. The latter, by the way, was announced the winner of this tender.

There were cases of scepticism towards architectural tenders. There, in 1905 pastors of the Catholic Church in Vilnius took the initiative to build a church dedicated to the Sacred Heart, but the bishop E. Roppas, whose opinion about tenders was rather sceptical (presumably, undoubted professionalism of an architect allowed choosing the non-formal way of organizing design works. - J. J.), commissioned the project to A. Vivulskis (Lukšionytė-Tolvaišienè 2002:97), whom he had known from childhood and trusted him.

The situation of architectural tenders in the interwar Lithuania was also characteristic of attention to buildings of great significance for the society and state, cultural objects and churches. Not by accident, many buildings that have "survived" tenders of that period do not lose their value even today. Yet this topic as well as that related to the soviet period is the subject of future research.

Currently, unfortunately, the legislation in Lithuania is incoherent and patchy. It does not define public interest or lawful expectations and other issues that respect the morality of the public relations in the area of architecture. Therefore, it becomes an informal indicator of mental perception in Lithuania (often lifeless, minimalistic and economically-based striving for a day-to-day benefit and sometimes, under the distorted privatization conditions, 


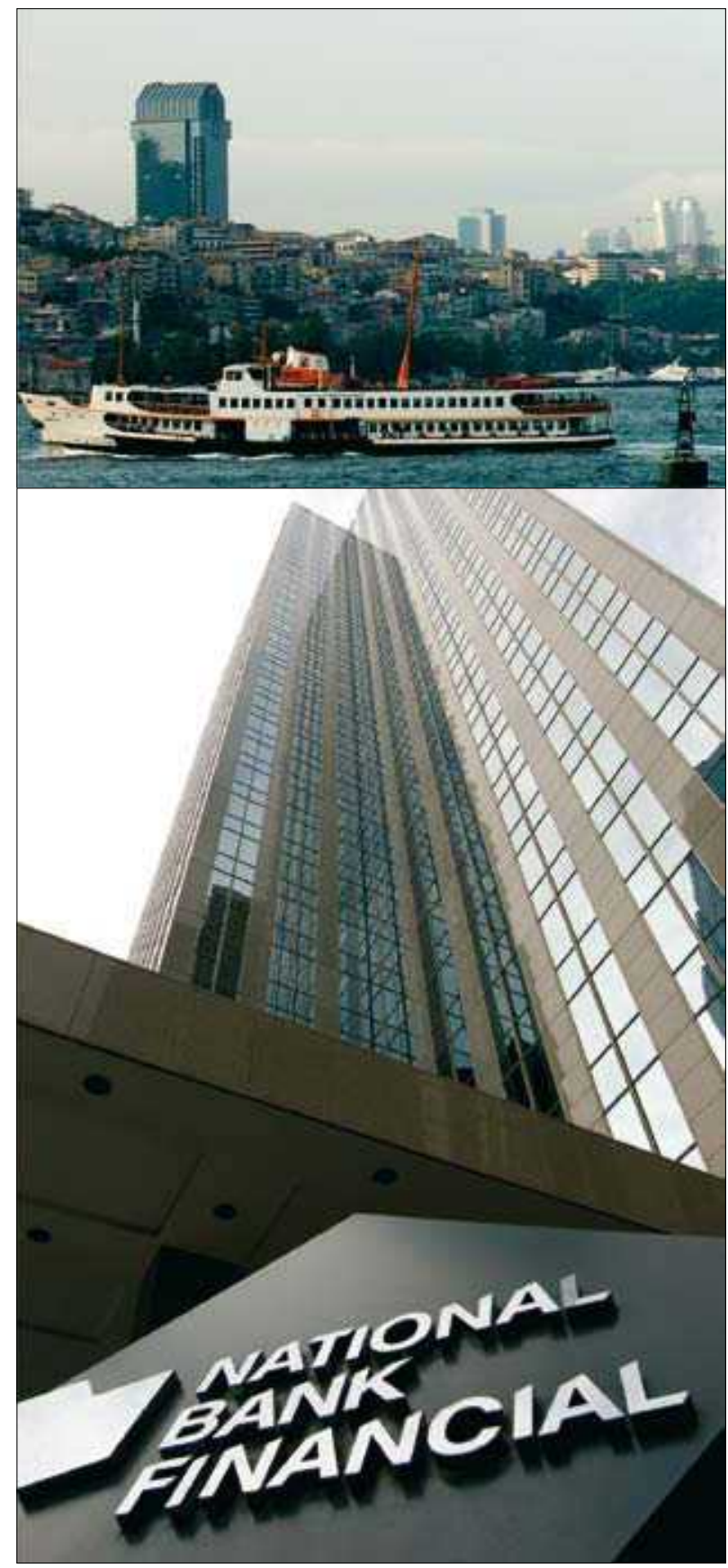

Fig. 4. Buildings of high-tech style architecture in Istanbul and Toronto (author's photos)

at the expense of benefit of other members of society). Unfortunately, they consider architectural activities as a technological part of construction complex. Such an attitude, as it can be understood primitively, emerged together with a period of a self-image of independence and freedom in all spheres as well as in that of architectural activities that co-occurred with the prosperity of the late modernism (high-tech) in the world of architectural stylistics (Fig. 3). Elements of architectural décor were eliminated from dominating geometric volumes of new buildings of the technical aesthetics in the context of rigorous "games" of the free market economy best corresponding with the image and prestige of business objectives (Fig. 4). Therefore, in the Lithuanian society, especially in that of non-professionals, the conception of technocratic architecture is reflected in the contemporary legislation of Lithuania that allows for occurrence of unprecedented situations enabling simplified understanding of the management of the urban architecture policy implementation, by "pushing forward" the importance of procedures into the priority position and failing to avoid conflict between the old and new. However, according to E. Navickiene, the issue between new and old architecture because of many actions started to be changed by the equality principal of new and historic architecture which highlighted the issue of good and bad architecture (because of lack of evaluation criteria - J. J.) (Navickienè 2006: 161). These processes are typical not only of Lithuania but also of other countries in the way to democracy. These trends are extremely evident in the political situation in Vilnius that changed after the local elections in 2007. Actions for continuity of the urban architecture policy implementation are not oriented for improving the achieved results.

Under such conditions the application of democratic planning principles in the development of urban architecture in Lithuania becomes inevitable and important for assessing:

- sustainable development;

- publicity of the process;

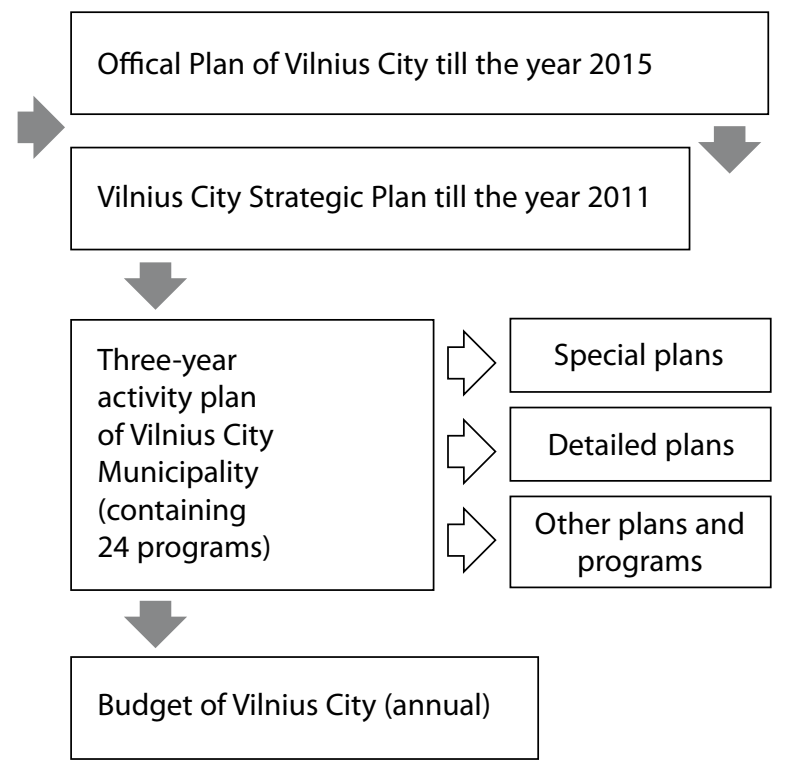

Fig. 5. Planning system of Vilnius City 
- cooperation (public-private partnerships);

- division of rights and duties;

- subsidiary.

Current legal acts existing in the country differently treat and present the definitions of plan contents of different levels. Speaking about the differences in the contents of these processes a lot of discussions arise in identifying the interrelationship between master plan (MP) and strategic plan (SP) and their role in an integrated municipal (or any other territory) system of plans (Fig. 5). The use of different formulations causes many uncertainties in defining the objectives and tasks of plans. Current laws on territories planning (TPL) (Law Amending... 2004) are not differentiated and are to be understood (and the society does so) as applicable to any size of the area, any level and type of planning. The ambiguity or absence of definitions not only confuse an organizer of planning activities, property owner and investor (they make their own interpretation of the contents), but also very often causes conflicting situations.

The traditions of good services in architectural activities are promoted in the EU member states due to understanding of a particular role of architecture in public life. It is required that national laws set adequate screening criteria and procedures in regulating the supply of quality services of architectural activities. It is important to ensure mutual balance between services, economic and life quality standards and artistry criteria. Therefore, in the words of the European Urban Charter, tenders in architecture may stimulate the birth of new ideas in urban development (Standing... 1997) and suppose conditions for sustainable procurement (?).

According to the legislation, in Lithuania a lengthy time is consumed for implementation of the service procurement process, and very often unclear criteria for the procurement of services have only a formal meaning of the contents of procedure (Fig. 6). Non-perfect law provisions do not ensure an objectively operating procedure of public procurement, hinder to make an immediate reaction to the challenging situation in the urban development market and even more highly discredit democratic principles for the procurement of services (Table 1 ).

Table 1. Analysis of duration of organising public procurement of services to prepare territory planning, urban projects according to the Law Amending the Law on Public Procurement of the Republic of Lithuania

\begin{tabular}{|c|c|c|c|}
\hline No & Actions & Executor & Duration \\
\hline 1 & $\begin{array}{l}\text { Decision regarding the development of territory } \\
\text { planning document: } \\
\text { a. Preparation of a decision and its submission } \\
\text { to the council (approval in committees) } \\
\text { b. Preparation of a task } \\
\text { c. Preparation of planning conditions }\end{array}$ & $\begin{array}{l}\text { Department of Urban } \\
\text { Development (DUD) } \\
\text { responsible units }\end{array}$ & $\sim 2$ months (officially ca 20 days) \\
\hline 2 & $\begin{array}{l}\text { Announcement of tender: } \\
\text { a. Preparation of tender conditions } \\
\text { b. Publication in press } \\
\text { c. Preparation of proposals }\end{array}$ & $\begin{array}{l}\text { Planning and Accoun- } \\
\text { ting Division (PAD) } \\
\text { Service provider }\end{array}$ & $\begin{array}{l}10 \text { days } \\
\text { At least } 52(36) \text { days in advance }(+3 \text { weeks in the } \\
\text { case of appeal) from announcement before su- } \\
\text { bmission of a notice and opening of envelopes }\end{array}$ \\
\hline 3 & $\begin{array}{l}\text { Opening of envelopes and analysis of bids } \\
\text { regarding compliance with conditions and task } \\
\text { a. Conclusion of preliminary sequence } \\
\text { b. Time for appeals } \\
\text { c. Announcement of a winner (contract signing } \\
\text { on procurement of service) }\end{array}$ & $\begin{array}{l}\text { Public procurement } \\
\text { commission }\end{array}$ & $\begin{array}{l}7 \text { days (minutes regarding preliminary priority and } \\
\text { announcement of a winner) } \\
10 \text { days }\end{array}$ \\
\hline
\end{tabular}

In total: 5-6 months

4 Contract implementation

Organizer will control $\sim 10-12$ months.

contract implemen-

tation

In total: 15-18 months 


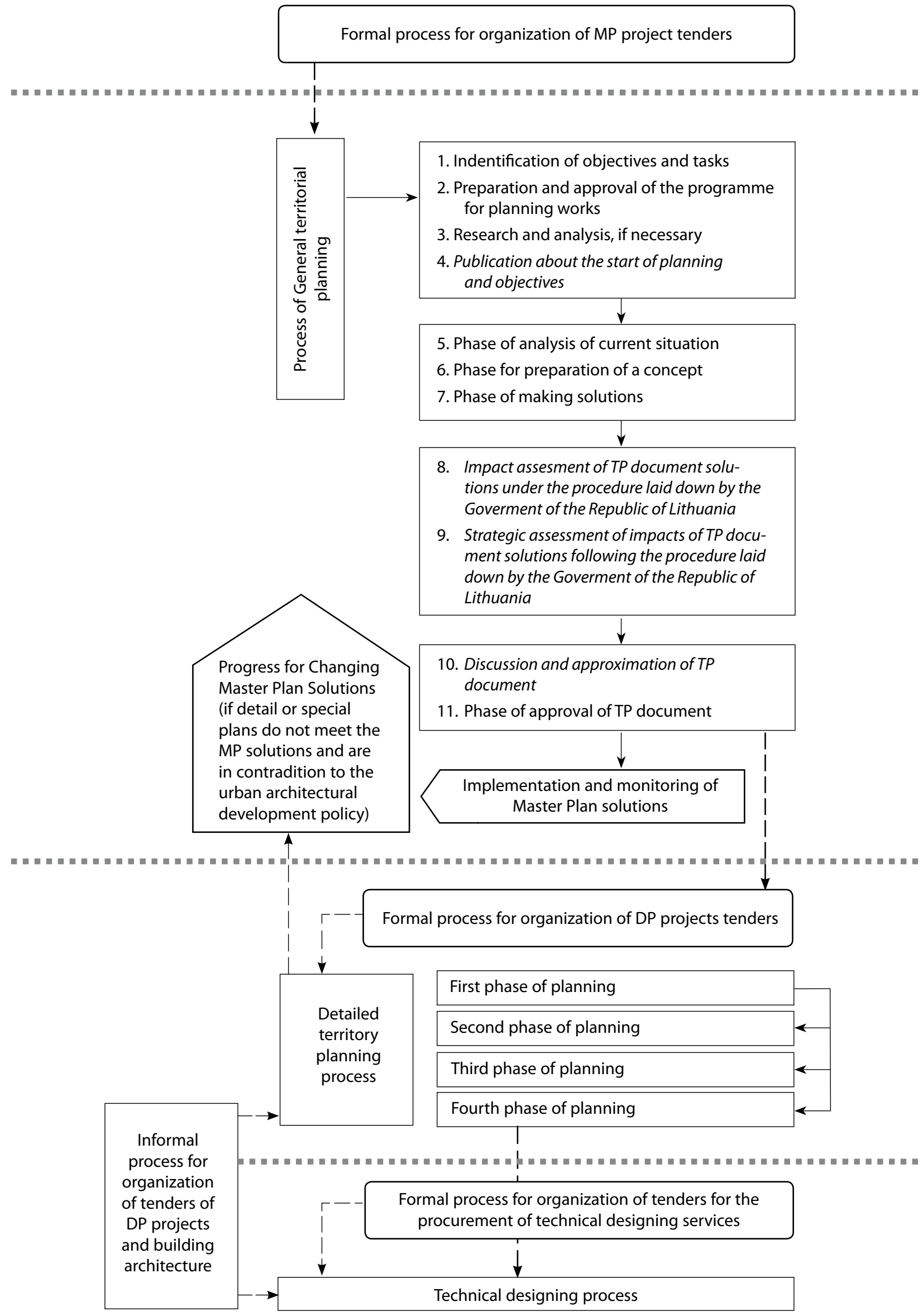

Fig. 6. Architectural activity and public procurement analysis of internecine interaction 


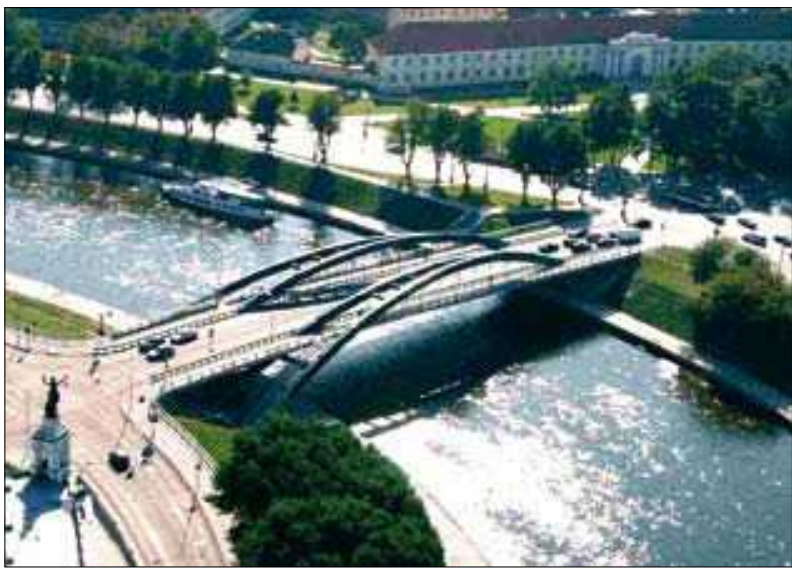

Fig. 7. King's Mindaugas Bridge in Vilnius

Current legal acts define (Law on Public... 1996) the following ways for the procurement of services:

1) open procedure tender;

2) restricted procedure;

3) competitive dialogue;

4) negotiated procedure with or without publication of a notice.

First, they are oriented only towards the lowest price for the procurement of services. Therefore, a questionable benefit of indicator to improve the quality of architecture causes discussions not only in the professional society.

According to the architect G. Čaikauskas (2005), new objects of architecture are evaluated absolutely conversely. The international commission evaluated King's Mindaugas Bridge (Fig. 7) as a valuable example of new architecture, though our heritage savers think that it is an invasion to the historic core of the city [Čaikauskas 2005]. Or, for instance, the newly-constructed tower-blocks for the famous Lithuanian fashion designer A. Pogrebnojus remind of warehouses and water-towers.

The scientist J. Minkevičius regrets about the quality of architectural activity in Lithuania and thinks that the previous results in architecture (should be understood as good - J. J.), originating and spreading creative ideas could be maintained only through competitions which nowadays are too rare that equity and competence of the evaluation commission forces us to doubt about the reached results. There appeared such architectural negativities as building-up of the right bank of the Neris (Figs. 8, 9) in Vilnius city that with its infantilism is characteristic of a European province (Minkevičius 2004). The world-wide architect D. Libeskind also notices that "modern architecture in Vilnius is supposedly in development and searching stage" (Leitanaite 2007).

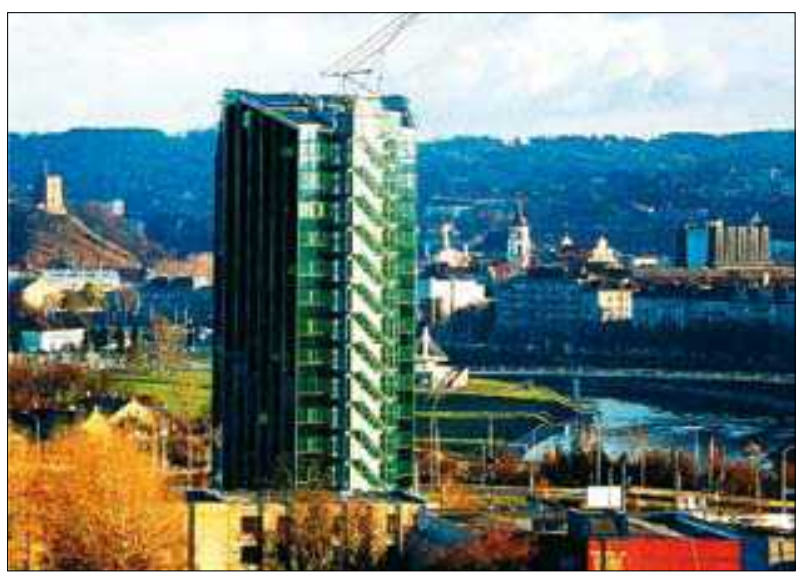

Fig. 8. Nowadays buildings are built only by the law of the market economics disobeying planning regulations that are set in competition conditions (Lagunovičius 2001). Enhanced mortgage rate got a huge amount of economic benefit (by competition rules the building height is 7 storeys; due to some circumstances the building became 16-storey during implementation)

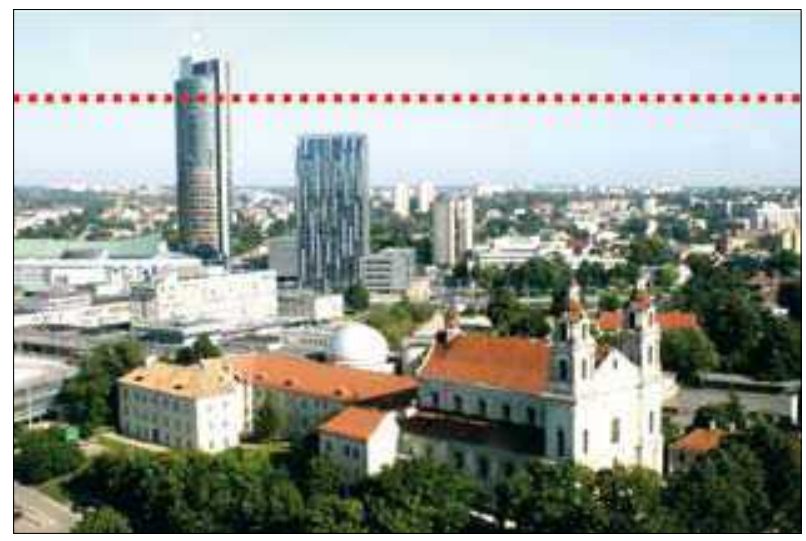

Fig. 9. An urban structure that was changed under the influence of informal interaction causing to reduce the area of the Municipality and commercial building density (author's photos)

\section{Summing-up}

Analysis of peripheries in the public procurement of services of architectural activities reveals that mainly three scenarios exist in the execution of the process:

- In that case the tenders are organised in full scale and are open in the manner established by legal acts- tenders based on formal procedures. When object is financed from budgetary funds and has a significant value to the architectural policy of the territory (e.g., for preparation of the Master Plan (MP) documents). Creative efforts of the society of professionals in Vilnius city were united as far back as 1994 when the first Master Plan of Vilnius city was started after the restoration of independence. With the participation of specialists from the international programme of 


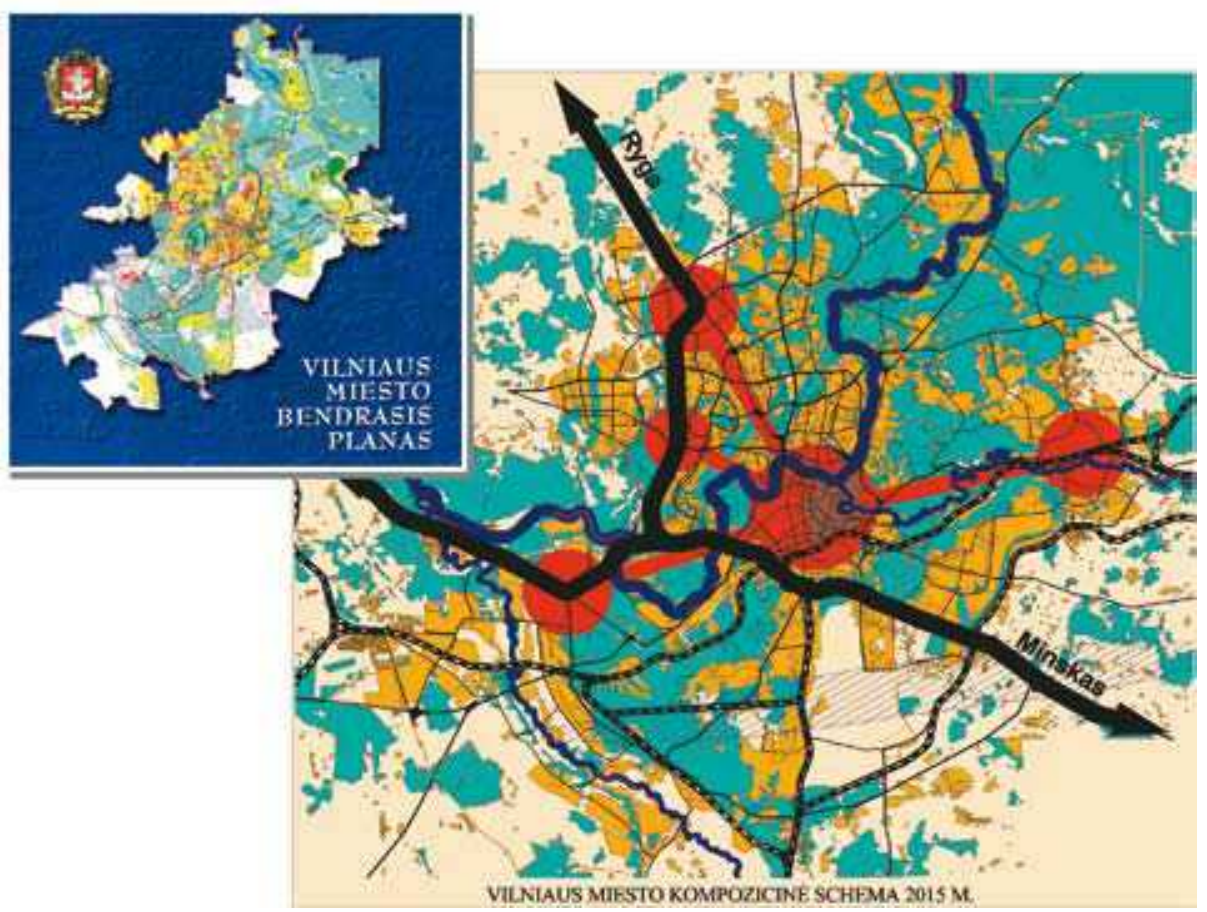

Fig. 10. The 7th Perspective Plan of Vilnius City development (Official Plan 1988-2005)

the Institute of Urbanistics of Canada, the practice of democratic planning was introduced. Three versions of urban architecture development were presented. The process stimulated creative and academic forces of the society but there was no absolute winner. A joint body of specialists summarised the material and formalised the results of decisions. The Master Plan after being approved by the City Council came into force in 1998 (Fig. 10) ${ }^{1}$.

In 1999 an open architectural tender of a formal nature called the professionals together for preparation of the concept of the right bank of the Neris and for generating architectural proposals for the object. The first place and the contract were won byE. A. Paslaitis and his colleagues. But when searching for an appropriate investor (by applying the PPP principle) and negotiating on conditions of participation, the territory plan of the winning project (splitting of the lot, changing of built-up principles, etc.) was already being revised. Due to the changed urban structure of the area, resulting from non-formal influence, the maximum height of buildings set to the tender

\footnotetext{
Vilnius City Council, Urban Development Department, Municipal Enterprise "Vilniaus Planas". Vilnius City Official Plan. Vilnius, 2000. 35 p.
}

project was increased. That caused tension in the society. The conflicting situation raised interest at the UNESCO headquarters.

Nevertheless, a winner of the tender does not guarantee continuity of the implementation of architectural objects. According to the current Lithuanian legislation, the winners of architectural tenders do not necessarily get the right to continue the designing and implementation of objects or to design them in the way they have been submitted for discussions by contest commissions.

- Semi-formal tenders are organized for large-scale objects which do not have influence on changing the urban structure. In such cases the process is formalized by a state or municipal institution which undertakes the responsibility of an organizer, however, its organization is funded from private funds. At first sight it seems that an attractive principle of publicprivate-partnerships is in operation, however, a state institution does not manage financial resources, and sometimes the management of tender results becomes complicated when the financer does not meet the requirements of territory planning documents at a strategic level, or if at that time there is no policy for developing the architecture of specific territories. In such cases tenders are implemented mostly through 
Table 2. Analysis for dissemination of procurement types at Vilnius City Municipality

\begin{tabular}{|c|c|c|c|c|}
\hline No & $\begin{array}{l}\text { Year of service } \\
\text { procurement }\end{array}$ & Object & $\begin{array}{l}\text { Number of } \\
\text { procurements }\end{array}$ & Type of procurement \\
\hline \multirow[t]{2}{*}{1} & 2005 & $\begin{array}{l}\text { Preparation of planning docu- } \\
\text { ments of Vilnius City municipal } \\
\text { territory (object of the contract } \\
\text { is defined on the basis of ac- } \\
\text { counting matters but not by } \\
\text { qualitative criteria for the deve- } \\
\text { lopment of urban architecture) }{ }^{1}\end{array}$ & 1 & $\begin{array}{l}\text { Open international public procurement tender } \\
\text { (where service procurement price exceeds } \\
\text { LTL 821000) }\end{array}$ \\
\hline & & Tripartite contracts & 44 & $\begin{array}{l}\text { Funds of private investors (semi-informal type } \\
\text { of procurement of services) }\end{array}$ \\
\hline \multirow[t]{2}{*}{2} & 2006 & $\begin{array}{l}\text { Services for preparation of spe- } \\
\text { cial heritage protection plans of } \\
\text { the cultural heritage objects of } \\
\text { the Municipality of Vilnius City }{ }^{2}\end{array}$ & 1 & $\begin{array}{l}\text { Open international public procurement tender } \\
\text { (where service procurement price exceeds } \\
\text { LTL } 821000 \text { ) }\end{array}$ \\
\hline & & Tripartite contracts & 46 & Funds of private investors \\
\hline \multirow[t]{2}{*}{3} & 2007 & $\begin{array}{l}\text { Services for preparation of spe- } \\
\text { cial heritage protection plans of } \\
\text { the cultural heritage objects of } \\
\text { the Municipality of Vilnius City }{ }^{3}\end{array}$ & 1 & $\begin{array}{l}\text { Open international public procurement tender } \\
\text { (where service procurement price exceeds LTL } \\
821000 \text { ) }\end{array}$ \\
\hline & & Tripartite contracts & 68 & Funds of private investors \\
\hline
\end{tabular}

1 Contract on provision of services No A64-7 of 16 May 2005

2 Contract on provision of services No A64-57 of 25 August 2006

3 Contract on provision of services No A64-12 of 13 February 2007 tripartite agreements (Table 2). A commission set up by a state institution decides upon the regulation of tender quality in architecture.

In 2001 a tender for arranging Šventaragis Square was organised. At that time the specialists of Vilnius City Municipality together with the members of the NGO Pilis, having prepared conditions of the monument management, announced an open tender for the Square between the streets of Šventaragis, Laurynas Stuoka-Gucevičius and Odminiai and Gediminas Avenue. The tender was organised to commemorate the architect Sigitas Lasavickis and the square was to be named Šventaragis Square. The purpose of this tender was to maximally reveal and highlight natural, historic and urban peculiarities of the place as of the part of the castle complex of Vilnius, to plan the public space of the city by marking places of confluence of rivers that had surrounded the castle and to compose them functionally by integrating into harmonised urban space of the city (Baranauskas 2001).

- A semi-formal architectural tender of 2005 for the project of Moscow Cultural and Information Centre at the crossing of Rinktine and Juozapavičius streets, organised by the private initiative, the Lithuanian
Union of Architects and Vilnius City Municipality but financed by the government of Moscow city, was not productive. Due to different conceptions in forming the urban structure of the territory and the architectural expression of the building, the works of students of Vilnius Gediminas Technical University and attitudes of architects from Moscow design group diverged at the stage of the concept formation. It was noted that the party that financed the project (it is usually the case of non-formal tenders) expected to realise its expectations at the maximum. The organising party (usually a municipal institution), as having no financial means of control and sometimes even policy of architecture development in specific urban territories, does not know how to complete the started procedures. There is no doubt, however, that generation of ideas, discussion of projects in the society is the most important positive factor.

An architectural-urban semi-formal tender, where assets of private investors methodically cooperate with Vilnius City Municipality in developing the idea of skyscrapers, identifying the need for the scopes of construction and solving problems of urban integration of the territory into the city structure, was 
successfully organised in the territory of the former soviet plant of electronic machinery "Velga". UAB "Akropolis" has intentions to transform this territory into a modern commercial and residential block.

- An informal type for organization of tender is selected for designing private objects. In this case teams of invited professionals or single architects are rallied. Then other types for organization of architectural tenders, which are simpler, based on logic and experience, start to operate. Semi-formal and informal "public" tenders are organized at the initiative of private investors. The data of investigation carried out by the author (Table 2) evidences that namely such public procurement cases mostly prevail in the area of architectural activities. Tenders are organized before the start of the process of detailed territory planning. Tender results become the indicators influencing the preparation of planning documents.

The Lithuanian legal acts define the procedures of public procurement and mostly assess the technical side of the process. For example, the List of Service A of Annex 2 to the Law on Public Services (2007) (types of procurement, criteria, procurement duration, procedure and the like are defined according to this list) groups the public procurement of services including other areas of an enterprise (municipality) activities, which sometimes do not have anything in common with architectural activities. By the abovementioned law, architectural services are mixed up with engineering and integrated engineering services; urban planning and landscape architectural services; engineering-related scientific and technical consulting services; technical testing and analysisservices and fully remove the specific role of an artist in the area of architectural activities.

\section{Conclusions}

1. The Lithuanian legal acts do not ensure the improvement of quality in architectural activities because the main criterion for assessing the organization of formal tenders remains an economic-financial indicator, and qualitative indicators are secondary. It is necessary to develop an integrated legislation and a well-formalized territory development planning and monitoring systems in the country at a state level with clearly defined definitions and assessment criteria which are interrelated. Differentiation of procedures, guarantee of publicity, and public participation in planning processes of different le- vels should become a priority task for the government.

Quintessential recommended actions include: - simplifying and improving procedures and benchmark costs, quality, supplier response (review of the quality of global procurement processes);

- full application of opportunities for socially, economically and architecturally preferential tender terms (contract terms and letters of understanding for social enterprises, employment, sustainable development, urbanism);

- improving outreach and education to small business and with local professional organizations.

2. The Lithuanian legal acts regulating the process of public procurement should be oriented towards the optimization of economic costs, time efficiency and minimization of costs as well as the quality improvement in architectural activities.

3. Evaluation of the analysis results show that if the public and government cooperation is inefficient and undemocratic, its drawbacks are highlighted (especially typical of countries whose democratic system is only in the process of formation, including Lithuania), causing constant conflicts, and it becomes more and more difficult to harmonize the actions in achieving a common objective.

4. The legal situation and management of the architecture of Lithuanian cities is based on the experience of democratic states only in a formal way. There is still no mechanism based on real participation of society in the decision-making process. Questions of hierarchy and social justice of participation of society in the decision-making process are still unsolved as well.

\section{References}

Buivydas, R. 1998. Construction in the Old Town. Measures of the typologycal model, in From the international seminar "Construction in a historic environment" reports. Vilnius, 23 Oct.

Baranauskas, V. 2001. Garažai prie Katedros aikštès - mankurtizmo triumfas, Archiforma 3: 95-96. ISSN 1392-4710.

Čaikauskas, G. 2005. Laiko peddsakai ant sostinès veido, Namų pasaulis/Lietuvos žinios/kovo 21 d., Nr. 12.

Hudson, K. 2007. Public procurement: a strategic level for territorial development. Feasibility study goals and methods, in Proc. of URBACT / Leveraging City Services (LCS) conference "Public Procurement Policy and small business: A strategic for promoting territorial economic growth". Hotel de Ville de Paris, 19 November 2007. 
Jakaitis, J. 2007. How is used Public Procurement as tool to improve local economy and architecture (main theses), in Public procurement policy and small business: a strategic for promoting territorial economic growth (An URBACT / Leveraging City Services (LCS) conference featuring policy by the Procurement Directors of the German cities of Leipzig and Rostock of the French cities of Saint Etienne, Roubaix and the Communaute Urbaine of Greater Lyon with visiting cities from Poland, Romania, Lithuania, Austria and Bulgaria). Paryžius, 2007 lapkričio 18-19 d.

Lagunovičius, A. 2001. UAB „Hanner“ administracinis pastatas, Archiforma 4: 97-102. ISSN 1392-4710.

Law amending the law on territory planning of the Republic of Lithuania, Žinios, 2004, No 21-617.

Law on public procurement of the Republic of Lithuania, Žinios, 1996, No 84-2000.

Interactive. [Looked on 18-10-2007]. Access on Internet: $<$ http://www.eurocities.eu>; <http://www.urban-matrix. net/glossary.htm>.

Leitanaite, R. 2007. Trys viename Guggenhaime, Statybu pilotas 10: 5 .

Lukšionytė-Tolvaišienè, N. 2002. Antanas Vivulskis. Tradicijų ir modernumo dermé. Vilnius: VDA leidykla. $163 \mathrm{p}$. ISBN 9986-571-79-0.

Minkevičius, J. 2004. Vingiuotas Lietuvos naujosios architektūros kelias, Statyba ir architektūra 9: 12-13.

Navickienè, E. 2006. Nauja architektūra istorinèje aplinkoje: kūrimo patirtis. Vilnius: Technika. 179 p. ISBN 9955-28-060-3.

Standing conference of local and regional authorities of Europe. European Urban Charter. European Printing House. 1997. Vilnius: Tomo J. Daunoros firma. $112 \mathrm{p}$. ISBN 9986-873-00-2.

\section{ARCHITEKTŪROS IR VISUOMENĖS SAৃVEIKA: VIEŠIEJI PIRKIMAI KAIP PRIEMONĖ GERINANT VIETINĘ EKONOMIKĄ IR ARCHITEKTŪRĄ}

\section{J. Jakaitis}

Santrauka. Vienas iš pagrindinių valdžios institucijų uždavinių - rasti būdų, kaip formuojant miesto architektūrą valdyti procesus ir sudaryti prielaidas visuomenei tapti naujo tipo aktyviai bendradarbiaujančia, dalyvaujančia miesto kūrimo procese pilietine visuomene. Šių problemų tyrimas yra svarbus siekiant gamtinès, ekonominès ir socialinės aplinkos, miestų architektūros darnos. Pagrindinis šio straipsnio tikslas - jevertinant demokratinių planavimo principų Lietuvoje taikymo ypatumus pabandyti atskleisti miestų architektūros formavimo kokybès problematiką viešųjų paslaugų pirkimų kontekste, įvertinti teisès aktais apibrežztu procedūrų efektyvumą architektūrinès kokybès požiūriu. Šiam tikslui pasiekti taikomi tarpdisciplininis, lyginamosios analizès metodai atskleidžiant dabartinių ịvykių specifiką.

Reikšminiai žodžiai: miestų architektūros formavimas; viešieji paslaugų pirkimai; darnioji teritorijų plètra; visuomenès dalyvavimas planavimo procese; miestų architektūros formavimo kompleksiškumas ir integruotas valdymas.

\section{JONAS JAKAITIS}

Doctor of the Humanities (architecture) (2007), Assoc Prof, Dept of Urban Engineering, Vilnius Gediminas Technical University (VGTU). Sauletekio al. 11, LT-2040 Vilnius, Lithuania. E-mail: j.jakaitis@am.lt; karolis1379@yahoo.com

Master of Architecture, VGTU, 1997. First degree in Urban Engineering, Vilnius Civil Engineering Institute (VISI, now VGTU), 1984

Projects: author or co-author of 19 research papers, national and international projects of architectural, urban design and planning. Publications: author of 17 scientific publications. Conferences: participant of 28 national and international conferences. Membership: member of the Lithuanian Union of Architects; member of Steering Committee of Urban Commission on Urban Planning of Union of Baltic Cities (UBC). Research interests: urban development programs, physical planning, urban planning, land use management, public participation. 